\title{
The UF/IFAS Strawberry Clean Plant Program ${ }^{1}$
}

\author{
Catalina Moyer, Natalia A. Peres, and Vance M. Whitaker ${ }^{2}$
}

\section{Introduction}

In Florida, strawberries are grown annually from September to April. In 2018, the crop was produced on about 10,000 acres and valued at over $\$ 300$ million (USDA 2018). Most Florida growers use cultivars developed by the UF/ IFAS strawberry breeding program at the UF/IFAS Gulf Coast Research and Education Center, which are licensed to strawberry nurseries by the Florida Strawberry Growers Association (FSGA). These cultivars are bred to provide the yield and quality traits needed by the Florida industry. However, if a new cultivar has the traits that Florida growers need but pathogen-tested planting stock is not available in a timely manner, the impact of the cultivar will be limited. The UF/IFAS Strawberry Clean Plant Program generates the pathogen-tested planting stock that nurseries and fruit growers require. The primary purpose of this publication is to educate both the industry and the public on the importance of the Clean Plant Program and the methods used to produce pathogen-tested planting stock for new cultivars.

\section{Strawberry Breeding and Plant Production}

The process of creating a new strawberry cultivar at UF/ IFAS is done through selective breeding, in which hybrid seeds are produced through cross-pollination. These seeds are germinated and grown into seedlings that have various combinations of traits. Every year thousands of new seedlings are evaluated, and some are advanced to later stages of testing. While new strawberry hybrids are propagated by seed, a seedling chosen for further evaluation is henceforth propagated vegetatively by runners (stolons). Once the selection is thoroughly tested and released as a new cultivar, nurseries need nuclear stock-also referred to as "mother" plants-to begin bulking up the cultivar. Starting with mother plants, at least three generations of runner multiplication are required, with each generation taking a year, until millions of commercial transplants are produced. Every fall, nearly 200 million strawberry transplants are sent to Florida from nurseries in northern California, Canada, and the Appalachian Mountains.

Strawberries are susceptible to many diseases that are difficult to control. Sufficient pathogen-tested nuclear stock of a new cultivar is necessary to facilitate commercial release, given the three- to four-year propagation cycle from mother plants to commercial fruiting plants. Thus, a division of the UF/IFAS strawberry breeding program called the Clean Plant Program was created with the goal of providing nurseries with pathogen-tested stock of new cultivars.

\section{Tissue Culture}

Meristem culture is a tissue culture procedure that utilizes meristems. It is useful for eliminating viruses and other pathogens acquired during field trials of advanced breeding selections that are candidates for cultivar release. Potted

1. This document is HS1343, one of a series of the Horticultural Sciences Department, UF/IFAS Extension. Original publication date October 2019. Visit the EDIS website at https://edis.ifas.ufl.edu for the currently supported version of this publication.

2. Catalina Moyer, biological scientist; Natalia A. Peres, professor, Plant Pathology Department; and Vance Whitaker, associate professor, Horticultural Sciences Department; UF/IFAS Gulf Coast Research and Education Center, Wimauma, FL 33598.

The Institute of Food and Agricultural Sciences (IFAS) is an Equal Opportunity Institution authorized to provide research, educational information and other services

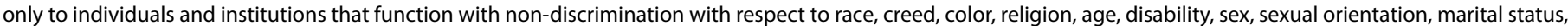

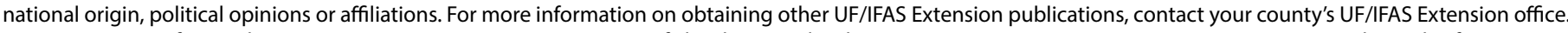
U.S. Department of Agriculture, UF/IFAS Extension Service, University of Florida, IFAS, Florida A \& M University Cooperative Extension Program, and Boards of County Commissioners Cooperating. Nick T. Place, dean for UF/IFAS Extension. 
plants of the selections are grown over the summer in a greenhouse isolated from other greenhouses. Rapidly growing runner tips are harvested and processed for meristem culture (Figure 1). High temperatures in the greenhouse during the summer are favorable for reducing virus replication in the meristems.

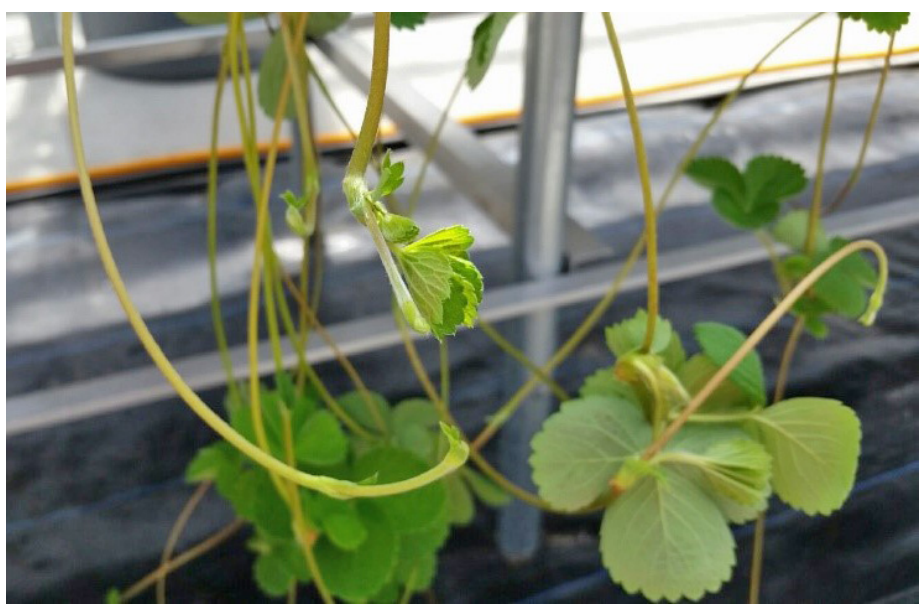

Figure 1. Strawberry runners used for meristem culture. Credits: Catalina Moyer, UF/IFAS

The youngest runner tips are surface-sterilized and placed within a laminar flow work cabinet or clean bench. Using the magnification of a stereo dissecting microscope, thin slices of a runner tip are cut with a scalpel horizontally until the apical meristem is located and transferred into a $13 \mathrm{~mm}$ test tube containing MS media (Murashige and Skoog salts, vitamins, sugar, agar and growth regulators) (Figure 2). Meristems that are less than $0.5 \mathrm{~mm}$ long are preferred because they are less likely to carry viruses or bacterial or fungal pathogens; however, their survival rate is lower compared to larger meristems. When meristems develop shoots, they are subcultured onto multiplication media containing a low concentration of plant hormones, just enough to induce shoot formation, resulting in 30 to 40 plantlets. Because our goal is not the mass propagation of in vitro plantlets, hormones are used judiciously and in vitro multiplication is limited.

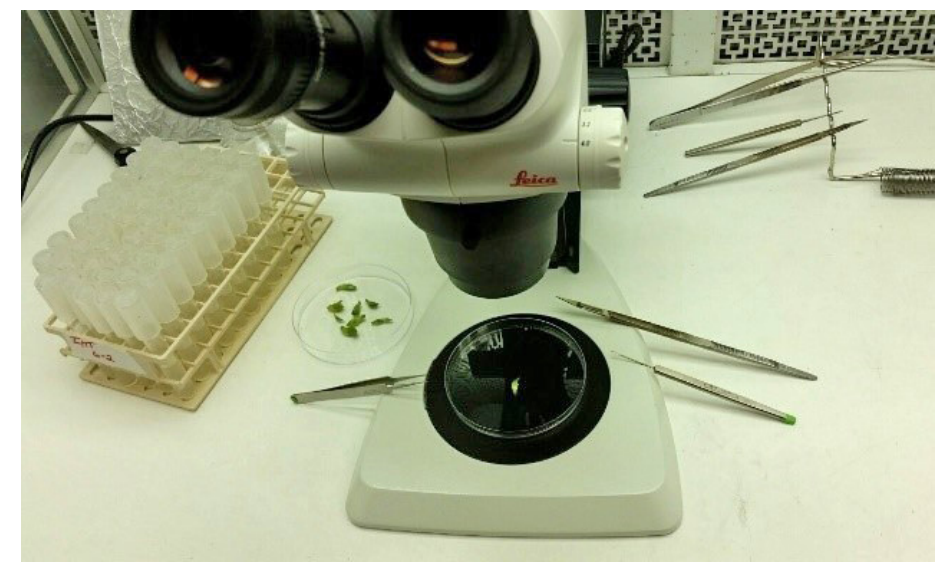

Figure 2. Meristem excision within a clean bench.

Credits: Catalina Moyer, UF/IFAS
During multiplication, shoots are transferred onto fresh media every four weeks (Figure 3). The number of subcultures during multiplication is limited to a maximum of 10 to reduce the risk of the production of off-types due to somaclonal variation.

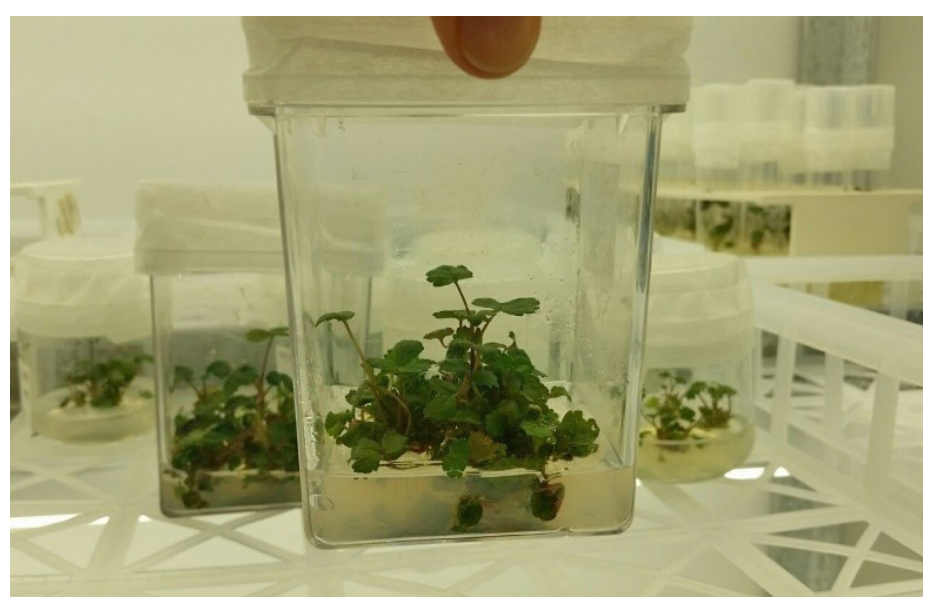

Figure 3. Strawberry shoots during multiplication. Credits: Catalina Moyer, UF/IFAS

Shoots that test negative for bacterial and fungal pathogens are divided, and some clumps of plantlets are placed in translucent, semipermeable bags for long-term storage at $4^{\circ} \mathrm{C}$, where they can survive for up to 14 months (Figure 4). Some other clumps are placed onto rooting medium where they grow taller and form roots before they are taken out of in vitro conditions (Figure 5).

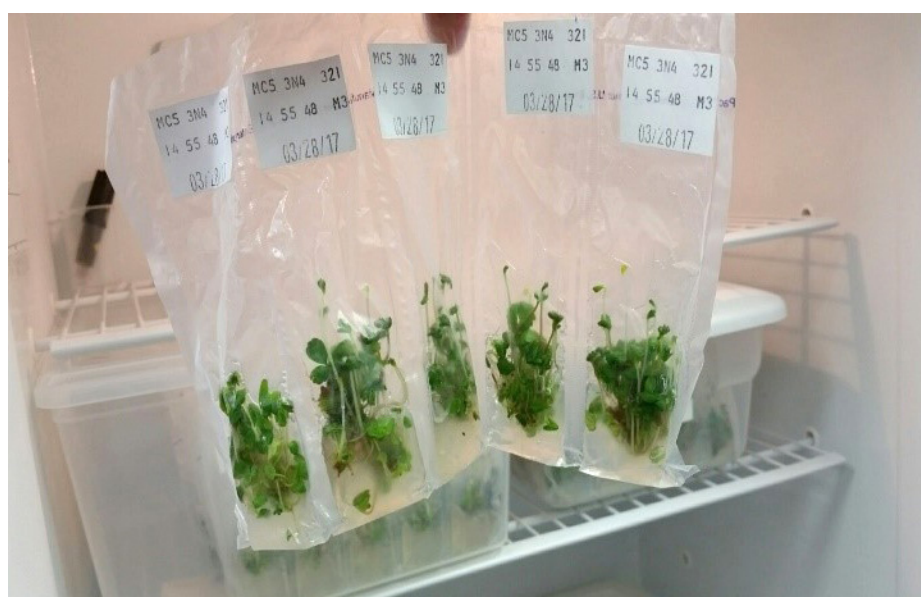

Figure 4. Strawberry plantlets in long-term storage. Credits: Catalina Moyer, UF/IFAS 


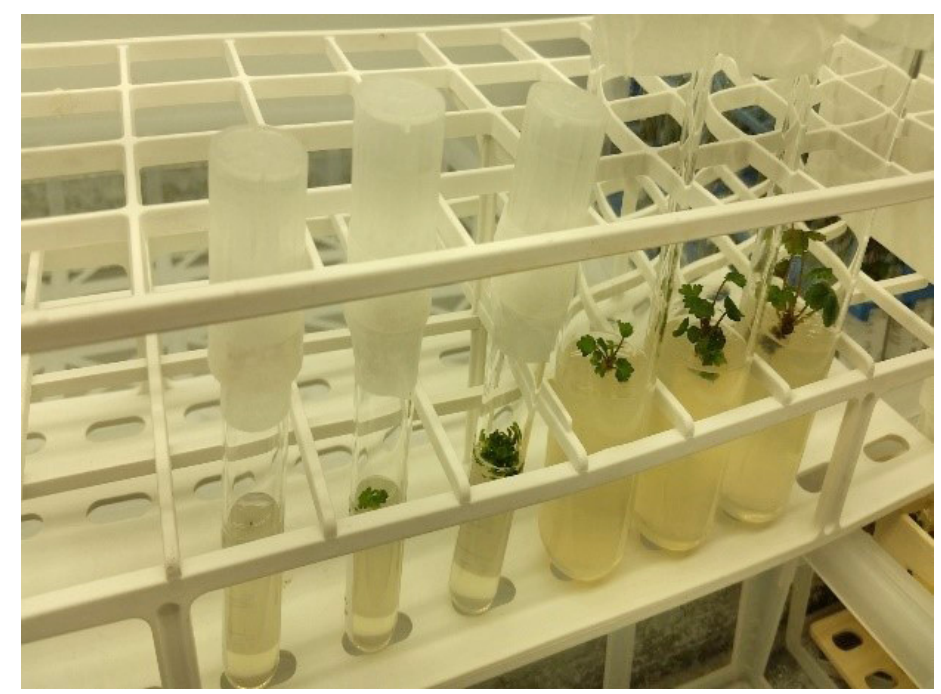

Figure 5. Strawberry tissue culture, from meristem (left) to fully developed plantlet (right).

Credits: Catalina Moyer, UF/IFAS

\section{Acclimatization of Meristem Plantlets}

In a growth room, rooted plantlets are removed from test tubes and are placed in the cells of trays filled with soilless, peat-based media inside a humid chamber (Figure 6). These plantlets need to be slowly acclimatized for a successful transition from in vitro to ambient conditions. The plants are allowed to develop in the growth room for a minimum of 8 weeks before virus testing procedures begin.

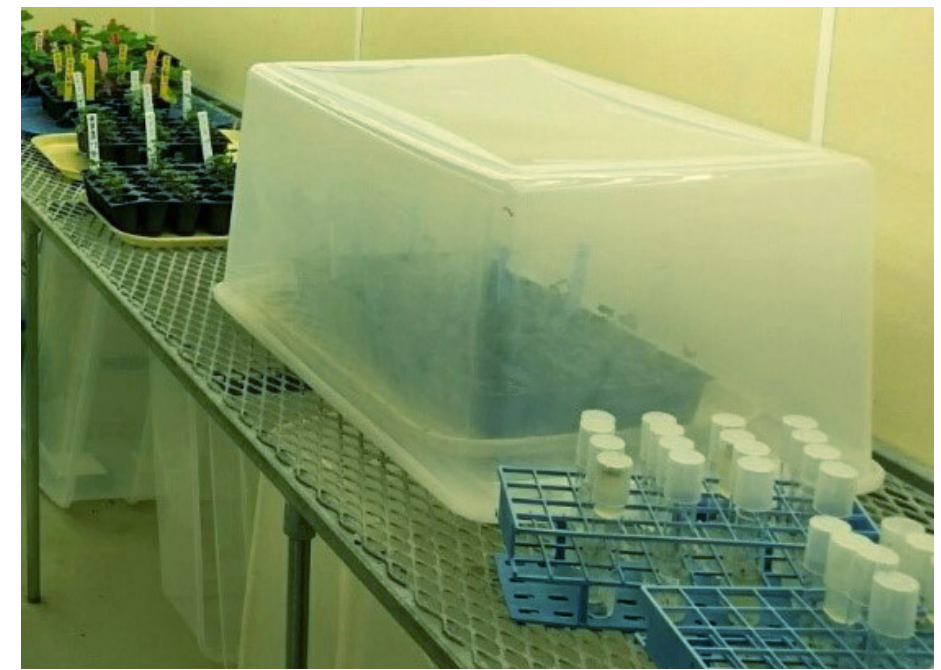

Figure 6. Acclimatization of meristem plants from test tubes in soilless media.

Credits: Catalina Moyer, UF/IFAS

\section{Pathogen Testing}

Testing for viruses and other pathogens occurs multiple times during the process using different techniques. The advance breeding selections are first tested when plants are actively growing and producing runners. Before harvesting runners for meristem culture, leaf samples from these plants are collected and sent to testing facilities for a multipathogen screen using enzyme-linked immunosorbent assay (ELISA) and polymerase chain reaction (PCR). Only plants that test negative are used for meristem culture. Additionally, during tissue culture, meristem tips that develop into shoots are indexed for bacteria and fungi before plantlets are placed in long-term storage or in rooting media. Four different types of media in petri dishes are used for detection of these pathogens, and small pieces of the plantlets are sampled for each medium. Plantlets that exhibit no pathogen growth or detection continue in the process.

Finally, leaf samples from acclimatized meristem plants are collected for an ELISA test performed at UF/IFAS GCREC. Meristem plants with negative results are sent to a commercial nursery, where they undergo the certification program of the California Department of Food and Agriculture (CDFA). At CDFA, plants are tested for multiple viruses by PCR and grafting onto biological indicators, sensitive plants that develop virus symptoms when grafted with an infected donor plant. Such plants may include clones of wild strawberry species (Fragaria vesca, Fragaria virginiana) and herbaceous species (Cucumis sativa, Chenopodium quinoa) (Table 1).

\section{Verification Trials}

Meristem plants are propagated via runners and placed in verification trials (Figure 7) at UF/IFAS GCREC, where performance is evaluated for multiple years. The strawberry breeder and the breeding staff regularly monitor the trials to assess for disease incidence or other problems. DNA markers are used to confirm that the plants are true to type, meaning that there are no mix-ups or mislabeling of cultivars. Only meristem plants without defects are released to nurseries as mother plants.

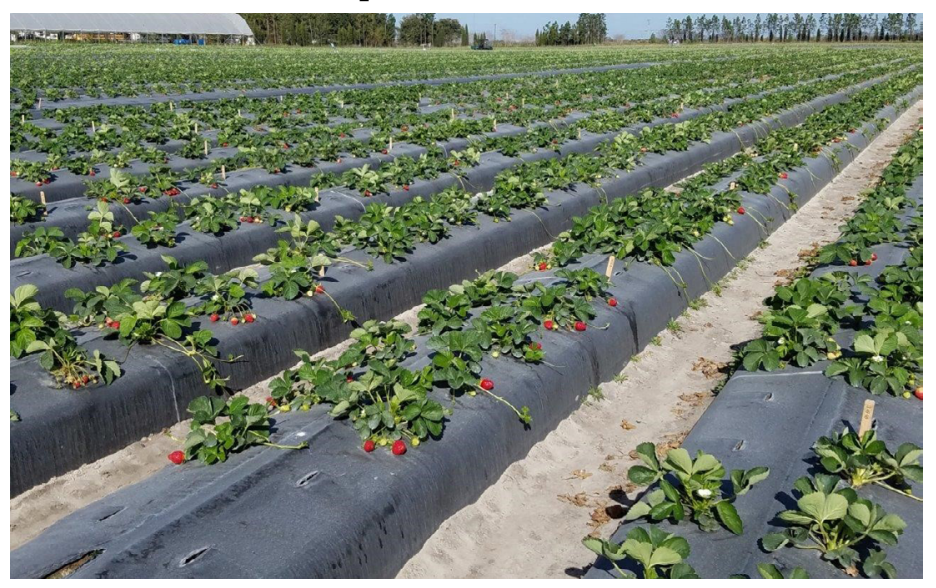

Figure 7. A verification trial at UF/IFAS GCREC.

Credits: Angelita Arredondo, UF/IFAS 


\section{Distribution of Pathogen-Tested Planting Stock}

Meristem plants of new cultivars are distributed to nurseries under transfer agreements and/or licensing contracts. The propagation cycle at the nursery level takes a minimum of three years, because the mother plants coming from tissue culture are juvenile and thus tend to exhibit more vegetative growth and be slower to flower and fruit than third-generation plants. Vegetative characteristics are an advantage in the nursery where runner production, not fruit production, is the goal. A single meristem plant can produce about one million plants in a three-year cycle or twenty million plants in a four-year cycle, depending on nursery conditions and practices.

\section{Conclusions}

The UF/IFAS Strawberry Clean Plant Program provides nurseries with planting stock of new cultivars. Because strawberry nurseries start the propagation cycle with pathogen-tested meristem plants, the spread of pathogens is less likely to occur. However, further measures at the nursery level must be in place to ensure that fruit growers in Florida and around the world will end up with healthy transplants. Ultimately, this program is an important bridge between the breeding program, the strawberry nursery industry, and the Florida strawberry industry.

\section{References}

Biswas, M. K., M. Hossain, and R. Islam. 2007. "Virus-Free Plantlets Production of Strawberry through Meristem Culture." World J. Agric. Sci. 3(6): 757-763.

Boxus, P., A. Jamali, J. M. Terzi, and O. Arezki. 2000. "Drift in Genetic Stability in Micropropagation the Case of Strawberry." Acta Hort. 530: 155-161.

Boxus, P. 1974. “The Production of Strawberry Plants by In Vitro Micro-Propagation." J. Hort. Sci. 49(3): 209-210. DOI: 10.1080/00221589.1974.11514571.

Dale, A., B. R. Hughes, and D. Donnelly. 2008. "The Role of Micro-Propagation in Producing Specific Pathogen-Tested Plants." HortScience 43: 74-77.

Debnath, S. C. 2003. "Micropropagation of Small Fruits." In Micropropagation of Woody Trees and Fruits. Edited by S. M. Jain and K. Ishii. Forestry Sciences, vol. 75. Springer, Dordrecht.
Martin, R. R., and I. E. Tzanetakis. 2013. "High Risk Strawberry Viruses by Region in the United States and Canada: Implications for Certification, Nurseries, and Fruit Production." Plant Dis. 97: 1358-1362. https://doi. org/10.1094/PDIS-09-12-0842-RE.

USDA. 2018. "Annual Statistics Bulletin. US Department of Agriculture (USDA), National Agricultural Statistics Service (NASS). https://www.nass.usda.gov/Statistics_by_State/ Florida/Publications/Annual_Statistical_Bulletin/2018/ index.php 
Table 1. UF/IFAS Strawberry Clean Plant Program pathogen testing.

\begin{tabular}{|c|c|c|c|c|c|c|}
\hline \multirow[t]{2}{*}{ Name of Pathogen } & \multicolumn{2}{|c|}{ Type of Test } & \multirow{2}{*}{$\begin{array}{c}\text { Selective } \\
\text { Media }\end{array}$} & \multicolumn{3}{|c|}{ Type of Pathogen } \\
\hline & ELISA & PCR & & Virus & Bacteria & Fungus \\
\hline Arabis mosaic virus (ArMV) & $\mathrm{X}$ & & & $x$ & & \\
\hline Beet pseudo yellows clostero virus (BPYV) & & $x$ & & $x$ & & \\
\hline Colletotrichum spp. & & & $x$ & & & $x$ \\
\hline Fungal species & & & $x$ & & & $x$ \\
\hline Phytoplasma spp. - MLO & & $X$ & & & $x$ & \\
\hline Phytophthora spp. (Phyt.) & $x$ & & & & & $x$ \\
\hline Raspberry ringspot virus (RpRSV) & $x$ & & & $x$ & & \\
\hline Strawberry crinkle virus (SCV) & & $x$ & & $x$ & & \\
\hline Strawberry latent ringspot virus (SLRSV) & $x$ & & & $x$ & & \\
\hline Strawberry mild yellow edge virus (SMYEV) & $X$ & & & $x$ & & \\
\hline Strawberry mottle virus (SMoV) & & $x$ & & $x$ & & \\
\hline Strawberry necrotic shock virus (SNSV) & & $\mathrm{X}$ & & $\mathrm{X}$ & & \\
\hline Strawberry pallidosis virus (SPV) & & $x$ & & $\mathrm{x}$ & & \\
\hline Strawberry vein banding virus (SVBV) & & $x$ & & $\mathrm{x}$ & & \\
\hline Tobacco ringspot virus (TRSV) & $\mathrm{X}$ & & & $\mathrm{X}$ & & \\
\hline Tobacco streak virus (TSV) & $x$ & & & $x$ & & \\
\hline Tomato black ring virus (TBRV) & $x$ & & & $x$ & & \\
\hline Tomato ringspot virus (ToRSV) & $x$ & & & $x$ & & \\
\hline Xylella fastidiosa (X. fastidiosa) & & $x$ & & & $X$ & \\
\hline Xanthomonas fragariae (X. fragariae) & & $\mathrm{X}$ & & & $\mathrm{X}$ & \\
\hline Yeast and bacteria (internal contamination) & & & $\mathrm{X}$ & & $x$ & \\
\hline
\end{tabular}

